УДК 657

DOI: $10.15673 /$ fie.v11i4.1549

\author{
Яценко В.Ф. \\ кандидат економічних наук, доцент \\ кафедра обліку і оподаткування \\ Херсонський державний аграрний університет \\ вул. Стрітенська, 23, м. Херсон, 73006 \\ E-mail viktorijajacenko@gmail.com \\ ORCID ID: 0000-0001-7127-1885
}

\title{
ВПЛИВ ЕВОЛЮЦІЙНОЇ ТРАНСФОРМАЦІЇ СОЦІАЛЬНО- ЕКОНОМІЧНОЇ СИСТЕМИ НА ТЕОРІЮ БУХГАЛТЕРСЬКОГО ОБЛІКУ
}

Статтю присвячено розгляду впливу трансформаційних перетворень соціально-економічного устрою суспільства в рамках формування постіндустріальної світової цивілізації на еволюційний розвиток теорії бухгалтерського обліку.

Виявлено причинно-наслідковий зв'язок між аномаліями традиційної теорії бухгалтерського обліку та зафіксованими фактами або проаналізованими явищами, які їх спричинили і мають ознаки тренду, що дозволило виокремити основні три тенденції постіндустріального етапу розвитку суспільства, які визначатимуть загальний вектор розвитку обліку на майбутнє: науково-технічний прогрес, глобалізація і відношення «людина-природа».

Вплив кожної з трьох тенденцій на стан теорії бухгалтерського обліку несе змістовний дуалізм, сприяє еволюційному розвитку та одночасно створює ризики і викликає загрози для існування.

Результат взаємодії тенденцій супроводжується «ефектом синергії», який розглядається як сукупний вплив, більший за просту алгебраїчну суму впливів кожної окремої тенденції, та створення якісно нової тенденції, якої не було раніше.

Ключові слова: теорія бухгалтерського обліку, постіндустріальна економіка, глобалізація, біосорера, техносфрера, ефрект синергії.

This work is licensed under a Creative Commons Attribution 4.0 International License http://creativecommons.org/licenses/by/4.0/

Постановка проблеми та її зв'язок з важливими науковими та практичними завданнями. XXI сторіччя характеризується еволюційними перетвореннями соціально-економічного устрою суспільства в рамках формування постіндустріальної світової цивілізації, яка зародилася в двадцяті роки минулого сторіччя, активно розвивалася у 1950-1960-ті роки, охопивши до 1980-тих років найбільш розвинені країни світу. «Коріння» постіндустріальної цивілізації та передумови іiі формування склалися на індустріальному етапі розвитку цивілізації. Зі зміною етапів цивілізації обгрунтовано пов'язують перехід від одного типу економіки до іншого, що суттєво впливає на еволюційний розвиток сучасних соціальноекономічних систем різного рівня.

Бухгалтерський облік як основне джерело задоволення інформаційних запитів різних груп стейкхолдерів бізнес-середовища знаходиться в епіцентрі поступових, але фундаментальних перетворень. Потенційний успіх підприємства залежатиме від того, наскільки адекватно функціонуватиме облікова система в умовах превалювання у складі активів об'єктів інтелектуальної власності, а цінність людського капіталу та знань перевищує вартість надсучасного обладнання та інших фізичних об'єктів.

Аналіз останніх публікацій по проблемі. Ак- тивним критиком традиційного підходу до бухгалтерського обліку виступає професор Пушкар М.С. (2010), який вбачає причину нежиттєздатності старої парадигми обліку «...в корінній зміні суспільноекономічного ладу в Україні та формуванні нового постіндустріального суспільства на основі досягнень науково-технічного прогресу» $[1$, с. 150$]$. 3 позицією професора погоджується вже нове покоління науковців (2017) «Проблема осучаснення системи обліку 3 кожним роком стає все більш актуальною для українського суспільства, оскільки їі архаїчність і невідповідність потребам бізнесу вражає. Вона відбиває рівень розвитку науки і потреби практики бізнесу індустріальної епохи кінця XVIII ст., коли принцип подвійного запису досяг свого апогею» [2, С.8]. Продовжуючи власні дослідження, Семанюк В.3. (2017) доводить необхідність кардинальної зміни теорії обліку, розглядає проблеми розвитку теорії бухгалтерського обліку та обгрунтовує необхідність ії перетворення відповідно до умов соціально-економічного розвитку та формування постіндустріального суспільства, використовуючи інформаційний підхід до бухгалтерського обліку, з метою формування інформації про внутрішнє і зовнішнє середовище підприємства [3].

Перегляду теоретичних основ бухгалтерсько- 
го обліку в умовах глобалізації та постіндустріального суспільства присвячено значну кількість робіт професора Голова С.Ф. [4-7]. Яремко І.Й. (2010) зауважує, що «Концептуальна основа сучасної теорії бухгалтерського обліку лише незначною мірою відповідає вимогам інформаційного суспільства та змісту інформаційно-інтелектуального економічного середовища» [8, С. 251]. Корягін М. В. (2014) основну задачу облікової науки в умовах сьогодення бачить у забезпечення адекватності методик обліку, використовуваних бухгалтерами підприємств, швидкоплинним змінам економічних систем [9].

Необхідно звернути увагу на схожість критичних зауважень до бухгалтерського обліку у наукових роботах зарубіжних вчених. Так, Myrelid А. та Olhager J. (2019) зазначають, що традиційний бухгалтерський облік (traditional accounting), було розроблено на початку двадцятого сторіччя. Цей підхід був адаптований для масового виробництва та складного сучасного виробництва [10]. Група авторів (Li Y. et al., 2016) пропонує трансформувати традиційну теоpiю бухгалтерського обліку (traditional accounting theory) і створити нову концептуальну основу фінансового обліку (new financial accounting conceptual) [11]. A Dillard J. (2016) на противагу загальноприйнятим засадам традиційного бухгалтерського обліку (traditional accounting) пропонує критичний облік (critical accounting), аналізуючи при цьому його модерністське походженням і здатність адекватно реагувати на вимоги мінливого (постмодерністського) світу [12].

Вивчення робіт зарубіжних авторів дає уявлення про значно ширше за вітчизняне охоплення факторів, що впливають на бухгалтерський облік, зокрема, певні автори (Archambault, J., Archambault, M., 2003) стверджують, що культурний, соціальний, економічний та політичний фактори можуть мати вплив на розкриття фінансової інформації, а також корпоративні системи (у розумінні IC) [13]. Лабіб К. (Labib K., 2002) визнає, що зіткнувшись 3 новою реальністю, бухгалтери у всьому світі усвідомили важливість створення та розкриття точної інформації про екологічні заходи та витрати компаній, які можуть вплинути на активи та пасиви компанії [14].

Професори бухгалтерського обліку Університету Вікторії Джуді Браун і Джессі Диллард (Brown J., Dillard J, 2015) підкреслюють вузьку направленість традиційного бухгалтерського обліку (traditional accounting's) на фінансові ринки і максимізацію добробуту акціонерів, його нездатність адекватно враховувати соціальні та екологічні наслідки діяльності і роль, яку він відіграє у розповсюдженні неоліберальної логіки [15]. Отже, результати вивчення академічних текстів вітчизняних $\mathrm{i}$ зарубіжних вчених щодо критики теорії бухгалтерського обліку на постіндустріальному етапі розвитку суспільства свідчать про певну невідповідність теорії бухгалтерського обліку трансформаційним процесам сучасної економічної системи.

Формулювання цілей дослідження. У запропонованій роботі автор поставив наступні цілі (1) виявити аномалії у традиційній теорії бухгалтерського обліку, спричинені фактами і явищами постіндустріальної економіки та встановити причиннонаслідковий зв'язок між ними; (2) виділити тенденції та дати оцінку їх впливу на стан і майбутній розвиток теорії бухгалтерського обліку.

Структура статті відповідає поставленим цілям і включає дві частини.

Виклад основних результатів та їх обгрунтування. Як зазначав автор статті у своїх попередніх роботах: «Еволюційний розвиток бухгалтерського обліку в Україні має відбуватися в тісному зв'язку зі змінами економічної ситуації в країні та відповідати сучасним науковим тенденціям» [16, с.42].

Виявлення аномалій у теорії бухгалтерського обліку, спричинених фактами і явищами постіндустріальної економіки та встановлення причиннонаслідкового зв'язку між ними. Постіндустріальна епоха як цивілізаційний етап розвитку суспільства неодмінно позначається на економічній системі, в якій пріоритетного значення набувають інформація та знання. Враховуючи напрацювання вітчизняних і зарубіжних авторів у сфері бухгалтерського обліку, наведемо основні критичні зауваження щодо теорії бухгалтерського обліку:

- історичність (відставання) даних бухгалтерського обліку;

- використання фактичної (історичної) оцінки активів і зобов'язань;

- обов'язковість використання єдиного грошового вимірника і подвійного запису;

- обмеженість і низька релевантність облікових даних і процедур бухгалтерського обліку для реалізації нових концепцій управління;

- формування і відображення лише фінансової інформації;

- багатоваріантність відображення в обліку господарських операцій, активів і зобов'язань через використання різних методологічних прийомів і професійного судження бухгалтера;

- обмеженість у часі та просторі, тобто відсутність даних про можливі майбутні події і фактори зовнішнього (макро-) середовища;

- невідповідність облікових і звітних даних запитам різних груп стейкхолдерів бізнес-середовища;

- відсутність чіткої термінологічної бази, пов'язаної 3 якісними характеристиками нових об'єктів обліку.

Традиційно до об'єктів бухгалтерського обліку відносили майно, капітал і зобов'язання, а також господарські процеси діяльності підприємства: постачання, виробництво і реалізація (збут). Поява нових об'єктів, особливо об'єктів інтелектуального потенціалу підприємства та тих, які пов'язують з отриманням майбутньої економічної вигоди, спричинила певні проблеми, насамперед, з ідентифікацією та оцінкою, отже, і з відображенням вартості на рахунках бухгалтерського обліку та у статтях фінансової звітності.

Оскільки знання зберігаються в людині, тому значення людських ресурсів переважає над матеріальними. Найбільш цінними якостями працівників стають освіченість, досвід, професіоналізм і експерт- 
не судження, а також здатність до навчання і креативність необхідні для формування каскаду інноваційних компетенцій працівників бухгалтерської служби. Необхідно звернути увагу на особливу роль вміння бухгалтера використовувати облікові дані для управління.

В постіндустріальному суспільстві особливого значення набуває якість інформації і наявність певних знань щодо ії використання. Традиційна теорія бухгалтерського обліку через існуючі обмеження не спроможна адекватно висвітлювати нові якісні характеристики об'єктів і господарські операції на рахунках обліку і формах звітності, в результаті асиметри- чність і різноспрямованість наявних облікових і звітних даних та інформаційних запитів різних груп стейхолдерів спричиняють аномалії бухгалтерського обліку.

До висвітлених фактів і явищ, які впливають на сферу економіки і викликають аномалії в теорії бухгалтерського обліку, необхідно додати орієнтацію на стратегічний розвиток, високий рівень ризиків i невизначеності, збереження екології і довкілля, виникнення мережевої організаційної структури компаній, глобалізація ринків, капіталу і діяльності компаній (рис. 1).

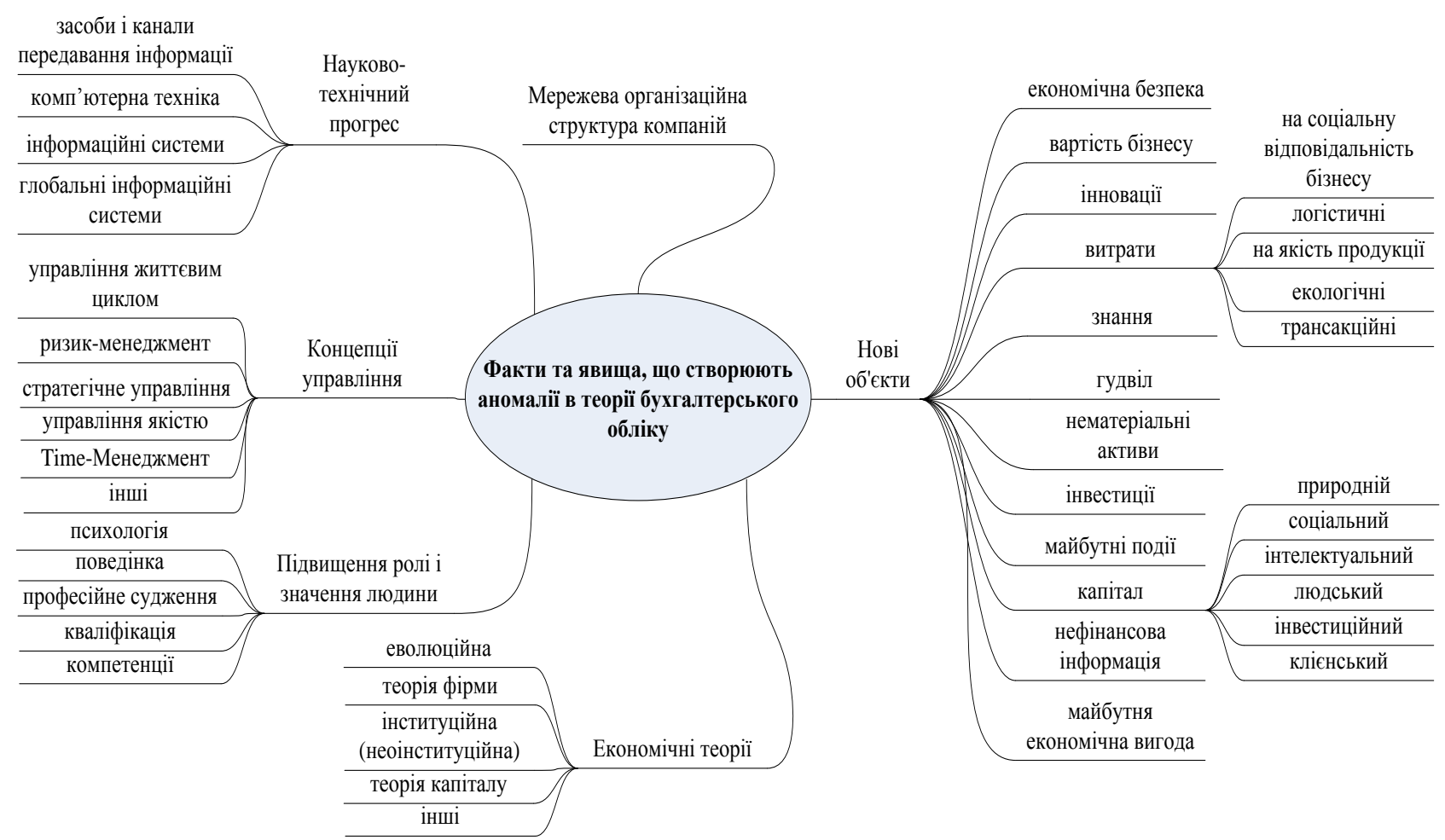

Рис. 1. Факти та явища, що створюють аномалії в теорії бухгалтерського обліку * *авторська розробка

Крізь всі публікації, з якими вдалося ознайомитися, червоною стрічкою проходить теза про обов'язкове врахування теоретичною основою бухгалтерського обліку нових реалій економічної системи.

Виділення тенденцій та оцінювання їх впливу на стан і майбутній розвиток теорії бухгалтерського обліку. Факти і явища, притаманні постіндустріальній економіці, визначають основні тенденції, які не втратять своєї актуальності у майбутніх періодах. В представленому дослідженні виділено три основних тенденції постіндустріальної економіки, які впливають на теорію бухгалтерського обліку як теоретичну основу системи бухгалтерського обліку: науковотехнічний прогрес, глобалізаційні процеси, і орієнтація на співвідношення «людина-біосфера». При цьому дві останні тенденції - науково-технічний прогрес, який вважають джерелом формування техносфери, i співвідношення «людина-біосфера», яке у вітчизняній науці асоціюють із ноосферою академіка B.I. Вернацького, мають діаметрально протилежне спрямування (рис. 2).

Як правило, в наукових роботах представлено однобоке уявлення про вплив еволюційних перетворень економічної системи на розвиток теорії бухгалтерського обліку, причому, увагу науковців зосереджено переважно на позитивному аспекті. Натомість змістовний дуалізм впливу тенденцій, які трансформують економічну систему, полягає у наступному: 3 одної сторони вони відкривають нові перспективи і можливості стійкого розвитку та вирішення існуючих проблем, з іншого, породжують нові виклики і загрози для виживання та забезпечення життєдіяльності системи бухгалтерського обліку: Виявлення і оцінка впливу тенденцій на теорію бухгалтерського обліку як теоретичне «ядро» системи бухгалтерського обліку потребує детального розгляду кожної з них. 


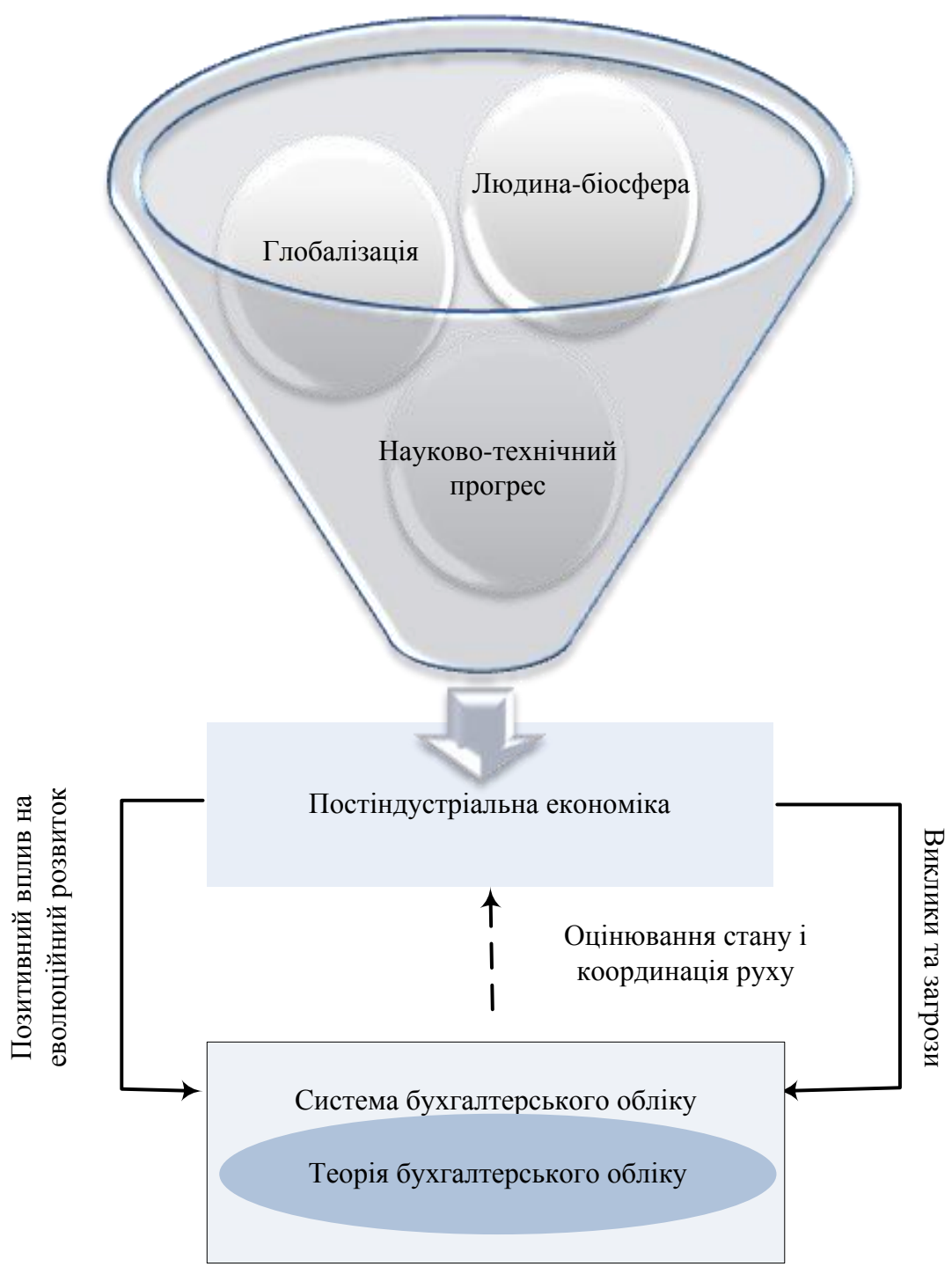

Рис. 2. Декомпозиція взаємозв'язку і взаємовідношення постіндустріальної економіки і теорії бухгалтерського обліку *

*авторська розробка

Досягнення науково-технічного прогресу. Кардинальна трансформація інформаційного і комунікаційного середовищ, основана на мережевій структурі, використанні новітніх інформаційнокомунікативних технологій і систем дозволяють вирішувати глобальні проблеми і економити час щодо формування, обробки, збереження і передавання інформації, а також зменшують можливість помилок, причинених людським фактором. Натомість, вони радикально змінюють уявлення про звичайні категоpiï, такі як дані, документ, підпис, реквізит тощо, а також впливають на техніку облікових процедур i технологію формування масивів даних та роботи 3 ними, порядок архівування і передавання документів і звітів. 3 огляду на наведені фактори, розвиток бухгалтерського обліку попадає в сферу інших наук $\mathrm{i}$ галузей знань, таких як інформатика, кібернетика, інші.

Згідно засад теорії інформації хаос (ентропія) і порядок (інформація), дорівнюють один одному, але протилежно спрямовані, іншими словами збільшення кількісної величини інформації одночасно збільшують порядок і хаос у системі. Так, для великих обсягів інформації, відомих як Big Data, потрібне додаткове програмне забезпечення, i мова йде не про використання, а управління даними. Здатність сучасних інформаційних систем і комп'ютерних засобів генерувати потоки інформації, створювати і зберігати дані практично необмежених обсягів і у різних аналітичних розрізах, призведе не до зростання ефективності використання облікових даних, а, навпаки, перешкоджатиме нормальному функціонуванню облікової системи, i, взагалі, ставить під сумнів ефективність бухгалтерського обліку як технології формування даних на основі подвійного запису.

Водночас, до бухгалтера як виконавця висувається додатковий комплекс вимог, пов'язаний не тільки з відповідним рівнем фахових знань і компетенцій, але й до психологічного стану, включаючи стійкість до психологічного напруження та стресів, здат- 
ність переносити значні інтелектуальні навантаження, адекватне сприйняття постійних інноваційних змін цифрового світу. До загроз і статті додаткових витрат для компанії необхідно віднести захист конфіденціальної і комерційної інформації, можливу непередбачувану втрату даних, несанкціонований доступ сторонніх осіб до інформаційної системи, тощо.

«Людина-біосфера». Співвідношення передбачає гармонійне співіснування соціального людства i біосфери. В царині нової філософії академік В.І. Вернацький передбачав еволюційний перехід біосфери до ноосфери під впливом наукової думки і людської праці.

Для вітчизнах вчених i практиків досить складно визначити цілі і вигоди найближчого майбутнього від впровадження екологічної і соціальної концепцій на українських підприємствах, крім очевидних, збереження довкілля і турботи про суспільство. Бухгалтер побачить лише додаткові ризики, обсяги роботи та збільшення витрат і податків. Більш того, бухгалтер сприймається топ-менеджментом компанії ключовим гравцем в розробці схем ухилення від сплати податків, які позбавляють державу необхідних доходів для соціальних інвестицій. Штрафні санкції і контроль не здатні зломити ситуацію, необхідно запровадити прозору та справедливу систему розподілення коштів державного і місцевих бюджетів, яка може спонукати компанії до відмови від податкових схем.

«Екологічний» контент у дослідженнях з бухгалтерського обліку і практичній діяльності, ототожнюється, у першу чергу, з сировинними, енергетичними і вуглецевими проблемами, зменшенням викидів у атмосферу і водоймища, а також фіскальним тиском та законодавчими вимогами на загальнодержавному і міжнародному рівнях. Потенційний вклад компанії у зміну клімату та розв'язання інших всеосяжних екологічних проблем, пов'язаний не тільки зі зростанням сплачених податків, а й значними вкладеннями в інноваційні проекти, які вимагатимуть залучення великих обсягів інвестицій. Однак, включення питань збереження екології і довкілля в сферу управління компанії безперечно призведе до збільшення соціального ефекту і зростання репутаційної привабливості бізнесу, одночасно вимагатиме адекватного відображення в обліково-аналітичній системі у вигляді додаткових об'єктів, зокрема екологічних витрат, що може стати інструментом фіскального i політичного тиску на бізнес i бухгалтера.

Основними цілями, які надають позитивного впливу на результати діяльності компанії, можуть стати: скорочення витрат за рахунок підвищення енергоефективності обладнання та ефективності використання сировини і матеріалів, а також зменшення репутаційних ризиків через схвалення заходів щодо зменшення забруднення навколишнього середовища 3 боку суспільства. Реалізація концепції загального збереження довкілля стане плідним джерелом натхнення для керівництва компанії лише за умови ефективного збору інформації в необхідних аналітичних розрізах.

Глобалізаційні процуеси. Безпосередній вплив глобалізації на систему бухгалтерського обліку проявляється через розвиток світового співробітництва. Глобалізація значно розширює «вікно можливостей» для національного бізнесу в обміні товарами і послугами, залученні інвестицій і міжнародного капіталу, доступі до інформації, технологій, інновацій і знань. Водночас, глобалізація посилює міжнародні інтеграційні процеси в області бухгалтерського обліку, основним з яких є запровадження міжнародних стандартів бухгалтерського обліку та фінансової звітності.

Масштабна цівілізаційна взаємодія, пов'язана з інтеграцією і гармонізацією національних облікових систем, допомагає подолати перешкоди на шляху до виходу на нові глобальні ринки та доступу до міжнародного капіталу. Проте цей процес обов'язково призведе до перегляду принципів формування звітної інформації, перебудову системи обліку тощо, а також він несе серйозні загрози втрати історичних напрацювань минулих поколінь щодо врахування рівня розвитку національної економіки країни, культурних, ментальних, релігійних і цівілізаційних особливостей нації.

Результат взаємодії тенденцій створює «ефект синергії» і посилює сукупний вплив на теорію бухгалтерського обліку. Не вдаючись до детального розкриття концепту категорії «синергія» («synergy») наукової теорії «синергетики», яка має коріння природничих наук, зазначимо, що під «ефектом синергії» розуміємо не тільки інтуїтивне розуміння опису стану речей, що зазвичай передається фразою Аристотеля, що ціле більше суми окремих частин, а й нову якість, отриману в результаті взаємодії і якої не було раніше. «Ефект синергії» від взаємодії тенденцій проявляється у наступному:

(1) Формування єдиного інформаційнокомунікаційного простору (Internet), створення глобальних пошукових систем (Google, тощо), баз даних (big data), соціальних мереж (Facebook, Twitter, Instagram) і мережевої організаційної структури компаній стали результатом взаємодії глобалізації з досягненнями науково-технічного прогресу.

(2) Включення у порядок денний економічної системи кожної країни соціально-культурних аспектів, розподілення відповідальності за вирішення планетарних проблем, пов'язаних із подоланням бідності та збереженням екосистеми - результат взаємодії двох трендів: глобалізації і співвідношення «людинабіосфера».

(3) Інформаційні технології, засновані на використанні «штучного інтелекту», спрямовані на створення, збереження, розподіл i застосування знань, які обумовлюють виконання функцій управління, та забезпечують економічний успіх підприємства. Необхідною складовою функціонування сучасної компанії стає спеціальне технічне і програмне забезпечення, що включає комплекс формалізованих методів управління та охоплює функції пошуку, вилучення, структурування, систематизації, а також аналізу, поновлення, поширення та генерації знань для прий- 
няття управлінських рішень. Поява і розвиток «штучного інтелекту», нейронних систем тощо це нова тенденція, якої не було раніше і яка створена у результаті перенесення законів біосфери у технологічне середовище.

Висновки та перспективи подальших досліджень. Таким чином, вивчення літературних джерел вітчизняних і зарубіжних авторів доводить схожість критичних зауважень щодо теорії бухгалтерського обліку, які визначаються соціальними, культурними, політичними, економічними і соціальними факторами. Зовнішне середовище впливає на теорію бухгалтерського обліку через тенденції:

(1) Науково-технічний прогрес проникає у сферу обліку через інформаційні системи і технології, автоматизовані мережі, масове оцифрування інформації тощо.

(2) Повернення до гармонії людини 3 природою через трансформацію виробничих процесів, трансформація свідомості самої людини через зміну способу життя, орієнтованої на збереження довкілля, проблеми соціального і екологічного характеру проявляються у необхідності відображення в обліку нових об'єктів і господарських операцій.

(3) Глобалізація вимагає стандартизації і гармонізації принципів обліку на міжнародному рівні.

Кожна тенденція має дуалістичну природу: 3 одної сторони, сприяє розвитку теорії у позитивному напрямі; з іншої, несе загрози і виклики для іiі існування, а їх сукупний вплив посилюється ефектом синергії. Під «ефектом синергії» розуміємо одночасно опис стану речей, коли ціле більше суми окремих частин, та нову якість, отриману в результаті взаємодії і якої не було раніше. Формування єдиного глобального цифрового середовища (Internet), глобальних пошукових систем (наприклад, Google), баз даних (big data), соціальних мереж (Facebook, Twitter, Instagram) і мережевої організаційної структури компаній стали результатом взаємодії глобалізації з досягненнями науково-технічного прогресу, а необхідність висвітлення в обліку і фінансової звітності інформації щодо вирішення проблем планетарного масштабу із збереження екосистеми для майбутніх поколінь і соціального спрямування результат взаємодії двох тенденцій: глобалізації і співвідношення «людина-біосфера». Не зважаючи на те, що науковотехнічний прогрес (техносфера) і «людина-біосфера» (ноосфера) мають два діалектично протилежні напрями розвитку суспільства, результат їх взаємодії проявляється у створенні «штучного інтелекту» для генерування i збереження знань для здійснення управлінських функцій і створення «корпоративної пам’яті» .

Встановлення причинно-наслідкового зв'язку між аномаліями теорії бухгалтерського обліку та фактами або явищами, які їх спричинили, виокремлення тенденцій постіндустріального етапу розвитку суспільства, які впливають на стан теорії бухгалтерського обліку, дозволяють продовжити наукові розвідки у напрямі визначення загального вектору та окреслення сценаріїв еволюційного розвитку теорії бухгалтерського обліку у майбутньому.

\section{Література}

1. Пушкар М.С. [та ін.] Сучасні проблеми розвитку системи обліку в Україні / Пушкар М. С. та ін. Тернопіль: Економічна думка, 2010. 267 с.

2. Пушкар М.С., Семанюк В.З. Актуальність розробки сучасної парадигми обліку // Інститут бухгалтерського обліку, контроль та аналіз в умовах глобалізації. Міжнародний науковий журнал. 2017. вип. 1-2. С. 7 20.

3. Семанюк В.3. Необхідність кардинальної зміни теорії обліку // Accounting \& Finance / Oblik i Finansi. 2017. вип. 78. С. $75-80$. C. 3-12.

4. Голов С. Система глобального бухгалтерського обліку // Бухгалтерський облік і аудит. 2010. вип. 3. 3. C. $3-13$

5. Голов С. Теорія багатоцільового бухгалтерського обліку // Бухгалтерський облік і аудит. 2011. вип.

6. Голов С. Сучасні підходи до теорії бухгалтерського обліку // Бухгалтерський облік і аудит. 2011. вип. 3. С. 18-23.

7. Голов С. Стан наукових досліджень з бухгалтерського обліку в Україні: деякі спостереження // Бухгалтерський облік і аудит. 2012. вип. 7. С. 3-9.

8. Яремко І.Й. Концепції і парадигми бухгалтерського обліку як система наукових основ теорії // Bicник Національного університету «Львівська політехніка». Менеджмент та підприємництво в Україні: етапи становлення і проблеми розвитку. 2010. вип. 691. С. 246-252.

9. Корягін М.Парадигмальне бачення розвитку бухгалтерської звітності // Бухгалтерський облік і аудит. 2014. вип. 12. С. 28-43.

10. Myrelid A., Olhager J. Hybrid manufacturing accounting in mixed process environments: A methodology and a case study //International Journal of Production Economics, 2019. T. 210. C. 137-144. doi: 10.1016/j.ijpe.2019.01.024

11. Li Y. et al. The Analysis for the Contradictions Between M\&A and Supply of and Demand for Accounting Information // Management \& Engineering, 2016. №. 24. (Sep 2016). C. 24-32. 
12. Dillard J. The «Sustainable Development» of a Critical Accounting Project // Pioneers of Critical Accounting. Palgrave Macmillan, London, 2016. C. 91-108. doi: 10.1057/978-1-137-54212-0_6

13. Archambault J., Archambault M. A Multinational Test of Determinants of Corporate Disclosure // The International Journal of Accounting, 2003. 38 (2), 173-194. doi: 10.1016/S0020-7063(03)00021-9

14. Labib, KA Suggested Framework of Managerial Environmental Accounting // Scientific Journal for Economics and Commerce., 2002. 3 (3).

15. Brown J., Dillard J. Opening accounting to critical scrutiny: towards dialogic accounting for policy analysis and democracy //Journal of Comparative Policy Analysis: Research and Practice. 2015. T. 17. №. 3. C. 247-268. doi: $10.1080 / 13876988.2014 .989684$

16. Яценко В. Побудова облікової системи підприємства на основі процесного підходу: теорія та практика // Бухгалтерський облік і аудит. 2017. вип. 2. С. 41-49.

Стаття надійшла 12.10.2019

Стаття прийнята до друку 26.10.2019

Доступно в мережі Internet 26.12.2019

\author{
Яценко В.Ф. \\ кандидат экономических наук, доцент \\ кафедра учета и налогобложения \\ Херсонский государственный аграрный университет \\ ул. Стритенская, 23, г. Херсон, 73006 \\ E-mail viktorijajacenko@gmail.com \\ ORCID ID: 0000-0001-7127-1885
}

\title{
ВЛИЯНИЕ ЭВОЛЮЦИОННОЙ ТРАНСФОРМАЦИИ СОЦИАЛЬНО- ЭКОНОМИЧЕСКОЙ СИСТЕМЫ НА ТЕОРИЮ БУХГАЛТЕРСКОГО YЧETA
}

Целью представленного исследования является выявление внутренних аномалий в теории бухгалтерского учета, вызванных фрактами и явлениями постиндустриальной экономики и установление причинно-следственной связи между ними, а также выделение повторяющихся трендов для установления устойчивых тенденций и оценки их влияния на состояние и будущее развитие теории бухгалтерского учета. Результаты изучения академических текстов отечественных и зарубежных ученых продемонстрировали сходство критических замечаний к теории бухгалтерскому учету на постиндустриальном этапе развития общества.

В статье зафиксированы фракты и проанализированы явления, которые определяют тренд на определенном интервале времени и существование которых способствовало появлению внутренних аномалий в теории бухгалтерском учете. Установление причинно-следственной связи между фрактами и явлениями и вызванными ими аномалиями в теории бухгалтерского учета позволило выделить три основные тенденции влияния на общий вектор развития учета в будущем: научно-технический прогресс, глобализационные процессы, ориентация на отношение «человек-биосфера». Каждая тенденция имеет дуалистическую природу: с одной стороны, способствует развитию теории в положительном направлении; с другой, несет угрозы и вызовы для ее существования, а их общее влияние усиливается синергетическим эффректом.

Формирование единой глобальной цифровой среды, глобальных поисковых систем, баз данных, социальных сетей и сетевой организационной структуры компаний стали результатом взаимодействия глобализации с достижениями научно-технического прогресса. Необходимость освещения в учете и финансовой отчетности информации по решению проблем планетарного масштаба по сохранению экосистемы для будущих поколений и социальной направленности - результат взаимодействия двух тенденций: глобализации и соотношение «человек-биосфера». Несмотря на то, что научнотехнический прогресс (техносфера) и «человек-биосфера» (ноосфера) имеют два диалектически противоположных направления развития общества, результат их взаимодействия проявляется в создании «искусственного интеллекта» для генерирования и хранения знаний для осуществления управленческих функций и создание «корпоративной памяти».

Ключевые слова: теория бухгалтерского учета, постиндустриальная экономика, глобализация, биосфера, техносфера, эффрект синергии. 


\author{
Yatsenko V. \\ Ph.D, Associate Professor \\ Department of Accounting and Taxation \\ Kherson State Agrarian University \\ st. Stritenskaya, 23Kherson, 73006 \\ E-mail viktorijajacenko@gmail.com \\ ORCID ID: 0000-0001-7127-1885
}

\title{
THE INFLUENCE OF THE EVOLUTIONARY TRANSFORMATION OF THE SOCIO-ECONOMIC SYSTEM ON ACCOUNTING THEORY
}

The aim of this study is to identify an influence of internal anomalies in accounting theory caused by facts and phenomena of postindustrial economy, and to establish cause-effect relations between them, as well to reveal repeated trends to establish stable tendencies and assess their impact on the state and prospects of accounting theory. Based on literature review of domestic and foreign scientists, we found the similarity of critical remarks to accounting theory at the post- industrial stage of society development.

Facts and phenomena that determine the trend at specific time and lead to internal anomalies in the accounting theory have been established in the article. The establishment of cause-effect relations between facts and phenomena and the anomalies caused by them in accounting theory allowed to identify three main trends of future accounting development: scientific and technological progress, globalization processes, focus on «human-biosphere» relationship. Each of these trends has a dualistic nature: on the one hand, it contributes to the theory development in a positive direction; on the other hand, it creates some threats and challenges for its extstence, while synergistic effect enhances their common influence.

Interaction between globalization and the achievements of scientific and technological progress lead to appearance of a single global digital environment, global search engines, databases, social networks and the network organizational structure of companies. On the other hand, interaction between globalization and «human-biosphere» lead to necessity to highlight information in accounting and financial reporting about solving global problems in order to save ecosystem for future generations. Despite the fact that scientific and technological progress (technosphere) and the «human - biosphere» (noosphere) have two dialectically opposite directions of society development, the result of their interaction is manifested in the creation of «artificial intelligence» for generating and storing knowledge for implementing managerial functions and creating «Corporate memory». ergy effect.

Keywords: accounting theory, postindustrial economy, globalization, biosphere, technosphere, syn-

\section{References}

1. Pushkar, M. S. (2010). Suchasni problemy rozvytku systemy obliku v Ukraini. Ternopil: Ekonomichna dumka.

2. Pushkar, M. S., \& Semaniuk, V. Z. (2017). Aktualnist rozrobky suchasnoi paradyhmy obliku. Instytut Bukhhalterskoho Obliku, Kontrol Ta Analiz v Umovakh Hlobalizatsii. Mizhnarodnyi Naukovyi Zhurnal, (1-2), 07-20.

3. Semaniuk, V. Z. (2017). Neobkhidnist kardynalnoi zminy teorii obliku. Accounting \& Finance, (78), 75-

80.

4. Holov, S. (2010). Systema hlobalnoho bukhhalterskoho obliku. Bukhhalterskyi Oblik i Audyt, (3), 3-12.

5. Holov, S. (2011). Teoriia bahatotsilovoho bukhhalterskoho obliku. Bukhhalterskyi Oblik i Audyt, (3), 3-13.

6. Holov, S. (2011). Suchasni pidkhody do teorii bukhhalterskoho obliku. Bukhhalterskyi Oblik i Audyt, (3), $18-23$.

7. Holov, S. (2012). Stan naukovykh doslidzhen $\mathrm{z}$ bukhhalterskoho obliku v Ukraini: deiaki sposterezhennia. Bukhhalterskyi Oblik i Audyt, (7), 03-09.

8. Yaremko, I. Y. (2010). Kontseptsii i paradyhmy bukhhalterskoho obliku yak systema naukovykh osnov teorii. Visnyk Natsionalnoho universytetu «Lvivska politekhnika». Menedzhment ta pidpryiemnytstvo $v$ Ukraini: etapy stanovlennia i problemy rozvytku, (691), 246-252.

9. Koriahin, M. (2014). Paradyhmalne bachennia rozvytku bukhhalterskoi zvitnosti. Bukhhalterskyi Oblik $i$ Audyt, (12), 28-43.

10. Myrelid, A., \& Olhager, J. (2019). Hybrid manufacturing accounting in mixed process environments: A methodology and a case study. International Journal of Production Economics, 210, 137-144. doi: 10.1016/j.ijpe.2019.01.024

11. Li, Y. (2016). The Analysis for the Contradictions Between M\&A and Supply of and Demand for Accounting Information. Management \& Engineering, (24), 24-32.

12. Dillard, J. (2016). The «Sustainable Development» of a Critical Accounting Project. Pioneers of Critical Accounting, 91-108. doi: 10.1057/978-1-137-54212-0_6 
13. Archambault, J., \& Archambault, M. (2003). A Multinational Test of Determinants of Corporate Disclosure. The International Journal of Accounting, (38 (2)), 173-194. doi: 10.1016/S0020-7063(03)00021-9

14. Labib, K. (2002). A Suggested Framework of Managerial Environmental Accounting. Scientific Journal for Economics and Commerce, (3 (3)).

15. Brown, J., \& Dillard, J. (2015). Opening accounting to critical scrutiny: towards dialogic accounting for policy analysis and democracy. Journal of Comparative Policy Analysis: Research and Practice, 17(3), 247-268. doi: 10.1080/13876988.2014.989684

16. Yatsenko, V. (2017). Pobudova oblikovoi systemy pidpryiemstva na osnovi protsesnoho pidkhodu: teoriia ta praktyka. Bukhhalterskyi Oblik i Audyt, (2), 41-49.

Received 12 October2019

Approved 26 October 2019

Цитування згідно ДСТУ 8302:2015

Available in Internet 26.12.2019

Яценко В.Ф. Вплив еволюційної трансформації соціально-економічної системи на теорію бухгалтерського обліку // Економіка харчової промисловості. 2019. Т.11, вип. 4. С. 71-79. doi: 10.15673/fie.v11i4.1549

Cite as APA style citation

Yatsenko, V. (2019). The influence of the evolutionary transformation of the socio-economic system on accounting theory. Food Industry Economics, 11(4), 71-79. doi: 10.15673/fie.v11i4.1549 